\title{
ResearchArticle
}

\section{Quantity and quality of bulbs and bulblets as influenced by plant spacing in Polianthes tuberosa at farmers field of Tumkur district}

\author{
NAGAPPA DESAI, CHANDRU PATIL AND B. MAMATHA
}

\section{SUMMARY}

A field experiment was conducted on quantity and quality of bulbs and bulblets as influenced by spacing in Polianthes tuberosa at farmers field of Tumkur district. The experiment consisted of three different plant spacing viz., $45 \mathrm{~cm} \times 30 \mathrm{~cm}$ $\left(\mathrm{S}_{1}\right), 30 \mathrm{~cm} \times 30 \mathrm{~cm}\left(\mathrm{~S}_{2}\right)$ and $30 \mathrm{~cm} \times 15 \mathrm{~cm}\left(\mathrm{~S}_{3}\right)$ with seven replications at farmers field and Randomized Block Design. The result of three year data showed the significant difference on growth, bulb quality, bulbs and bulblets yield as affected by spacing. The spacing of $30 \times 30 \mathrm{~cm}$ was found to be optimum for better growth and recorded significantly highest plant height $(53.57 \mathrm{~cm})$ at 180 days after planting, maximum number of leaves per plant (111.78) and side shoots per pant (21.13) at 360 days after planting, which was at par with $45 \times 30 \mathrm{~cm}$ spacing. Bulbs and bulblets characters such as maximum number of bulbs per plant (16.80) and bulblets per plant (14.02), size of mother bulb $(4.68 \mathrm{~cm})$, daughter bulbs $(3.77 \mathrm{~cm})$ and clump weight $(455.10 \mathrm{~g})$ were recorded significantly at wider spacing $(45 \times 30 \mathrm{~cm})$, whereas lowest was recorded at a closer spacing $30 \times 15 \mathrm{~cm}$ due to lesser competition between plants for source of light, moisture, space and nutrient and as consequence showed better physiological activities, which in turn reflected improvement of bulb yield.

Key Words : Bulbs, Bulblets, Clump, Multiplication, Productivity, Spacing, Yield

How to cite this article : Desai, Nagappa, Patil, Chandru and Mamatha, B. (2017). Quantity and quality of bulbs and bulblets as influenced by plant spacing in Polianthes tuberosa at farmers field of Tumkur district. Internat. J. Plant Sci., 12 (2): $216-219$, DOI: 10.15740/HAS/IJPS/12.2/216-219.

Article chronicle : Received : 18.04.2017; Revised : 23.05.2017; Accepted : 13.06.2017

\section{MEMBERS OF THE RESEARCH FORUM}

Author to be contacted :

NAGAPPA DESAI, Krishi Vigyan Kendra (UAS), Konehalli, TUMKURU (KARNATAKA) INDIA

Email : agridesai@gmail.com

\section{Address of the Co-authors:}

CHANDRU PATIL, Agricultural and Horticultural Research Station, SRINGERI (KARNATAKA) INDIA

- - - - - - - - - -

B. MAMATHA, Krishi Vigyan Kendra (UAS), Konehalli, TUMKURU (KARNATAKA) INDIA 